\title{
RPTPs in axons, synapses and neurology
}

Andrew W Stoker

\begin{abstract}
Receptor-like protein tyrosine phosphatases represent a large protein family related to cell adhesion molecules, with diverse roles throughout neural development in vertebrates and invertebrates. This review focuses on their roles in axon growth, guidance and repair, as well as more recent findings demonstrating their key roles in pre-synaptic and post-synaptic maturation and function. These enzymes have been linked to memory and neuropsychiatric defects in loss-of-function rodent models, highlighting their potential as future drug targets.
\end{abstract}

\section{Introduction}

Receptor-like protein tyrosine phosphatases (RPTPs) were discovered in the late 1980's and are classified according to ectodomain structures [1]. Many are still being orphan receptors. Due to their developmental expression patterns, these phosphatases soon became a focus of interest in developmental neurobiology. A great deal has now been learnt about the expression, structures and cellular functions of these enzymes. Here we will explore both historical and recent research in three broad areas of RPTP function: (i) axon growth, guidance and regeneration; (ii) synaptogenesis and plasticity; (iii) neurological disorders and disease (Figure 1). As we are restricted for space, the reader will be referred to several excellent, focussed reviews that cover these individual areas.

\section{RPTPs in axon growth, guidance and regeneration}

RPTPs have long been implicated in the control of axon growth and guidance. Several excellent reviews are published with more detailed information [2-5].

\subsection{Drosophila RPTPs}

Drosophila has 6 RPTP genes, DLAR, DPTP69D, DPTP10A, DPTP99A, DPTP52F, DPTP4E, only three of which have clear mammalian orthologues [1]. Each influences the growth and guidance decisions of several stereotypical axonal pathways in the embryo stage of Drosophila development [3]. These have been studied largely in CNS longitudinal fascicles, the neuromuscular system (ISN and SN nerves and their targets), mushroom body neurons and in photoreceptor axon guidance. These have highly reproducible axon growth and guidance programmes that are amenable to genetic manipulation. Fly RPTPs 
control growth cone fasciculation to nerve tracts, defasciculation at choice points, recognition of targets, and establishment of stable synaptic contacts. Where directly investigated, RPTP ectodomains have been shown to be essential for these roles, whereas active catalytic domains are not always necessary. For example, DPTP69D controls choice point de-fasciculation of SNb axons requiring catalytic function [6]. In contrast, ommatidial R7 axon targeting requires DLAR, but not its catalytic capacity [4, 7]. The general conclusion is that both the adhesive functions and catalytic function of RPTPs can play important roles in axonal development, working alongside other well established adhesion and signalling systems. Several studies demonstrate that the 6 fly RPTPs have some functional redundancy, but can also synergise and counteract each other [8-12]. These relationships differ depending on which axon guidance model is studied and Jeon has proposed a network of potential interactions [10] (adapted in Figure 2).

Ligands have been identified for DLAR and PTP10D. DLAR functionally interacts with proteoglycans during synapse formation [13] (see below) and during ISNb motor axon guidance [14]. DLAR also interacts in trans with cadherin to control targeting of R1-R6 photoreceptor axons to the optic lobe lamina [15]. This latter interaction requires the pre-synaptic, intracellular interaction of DLAR with liprin- $\alpha$, but does not necessitate catalytic activity in DLAR. A ligand has recently been identified for PTP10D. Sas, a membrane protein expressed in most CNS cells $[16,17]$ binds specifically to PTP10D in trans, supporting a functional interaction that prevents unnecessary midline crossing of commissural axons. Interestingly the distinct midline axon phenotype of Ptp10D Ptp69D double mutants can be partly mimicked by Sas Ptp69D double mutants, supporting the conclusion that Sas is indeed a Ptp10D ligand. The signaling downstream of DPTP10D also appears to be shared with Ptp69D.

\subsection{Vertebrate RPTPs.}

There are 21 mammalian RPTPs. Here we limit discussion to those RPTPs most clearly implicated in nerve growth, guidance or regeneration (Figure 1). The type IIB RPTPs are discussed in detail elsewhere in this volume.

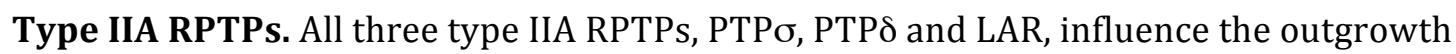
of neurites and axons in cell culture models and in vivo [2]. These RPTPs are immunoglobulin (Ig) superfamily cell adhesion molecules, with alternative isoforms generated through differential mRNA splicing. Such isoforms can have quite distinct ligand binding properties, which will in turn likely affect the degree and specificity of influence over neurite behaviour. All three RPTPs can promote neurite outgrowth in a 
cultured retinal neurons [18], hippocampal neurons [19, 20] and PC12 cells [21]. These experiments demonstrated neurite promotion non-cell-autonomously $[18,20]$ by isolated ectodomains from these RPTPs, as well as cell-autonomously through endogenous RPTP actions [21].

To effect such neurite control, RPTPs need ligands. Of particular interest are the proteoglycan ligands of PTPo. Both heparin sulphate proteoglycans (HSPGs) and chondroitin sulphate proteoglycans (CSPGs) bind to PTPo and these ligand classes may have opposite influences over axon elongation [22]. Specifically, HSPGs are proposed to induce PTPo dimers, inactivating catalytic function and facilitating axon elongation. In contrast CSPGs may force PTPo monomer formation, enzyme activation and signals that inhibit growth cone movement [22]. The structural basis for these interactions has been ascertained and is discussed in (see Coles chapter). Interestingly, there is an evolutionary correlate of these findings in Drosophila, since DLAR, the orthologue of mammalian type IIA enzymes, binds HSPGs Dally-like and Syndecan, eliciting distinct effect on synapses (see below).

In Xenopus all three type IIA RPTPs can influence retinal axon guidance [23] . In the chick embryo model, the outgrowth of the hindlimb anterior iliotibialis nerve is stunted when PTPo and PTPS expression is knocked down with siRNA in ovo (and the type III PTPRO; see below) [24]. In the chick model once again, PTPo was shown to control the outgrowth and targeting of the optic axons to their tectal targets [25]. Although mice lacking PTPo do not show evidence of axon guidance defects, loss of function (LOF) of PTPo and PTPס reveals a synthetic genetic relationship[26]. When both RPTPs are depleted, the phrenic nerve innervating the diaphragm initially extends normally to its target, but then fails to maintain contact and degenerates. This indicates redundant actions of these RPTPs, in a very specific axonal context. It is unclear why other nerves that co-express these RPTPs are not affected, but further levels of redundancy with other RPTPs cannot be ruled out.

\section{Type III RPTPs.}

PTPRO. SiRNAs targeting Ptpro in the chick embryo caused aberrant outgrowth of the dorsal hindlimb motor nerve[24], including complete loss of the nerve, poor outgrowth or fasciculation defects. These are greater effects than seen with siRNAs specific for

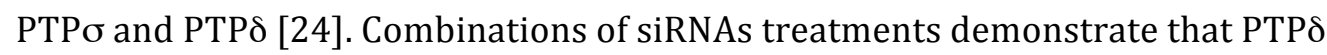
partially suppressing the PTPRO LOF phenotype. This was the first demonstration that vertebrate type III and type IIA RPTPs can counteract each other's actions in axon growth and guidance, paralleling findings with DPTPs (see above; Figure 2). 
PTPRO has also been implicated in controlling axon guidance in the avian visual system [27]. PTPRO can enzymatically target and suppress the signalling capacity of Ephrin receptors EPHA and EPHB, which in turn modifies axon guidance. When PTPRO is experimentally suppressed in cultured retinal axons, this leads to hypersensitivity to ephrins. In ovo, PTPRO suppression leads to retinotopic projection defects and failure to arborize with tectal targets. This phosphatase is therefore required for retinal axon growth and target recognition, acting through Ephrin/EPH pathways. PTPRO may therefore act alongside PTPo in guiding retinal axons [25]. Lastly, in mice lacking PTPRO, there is evidence of defective spinal axon guidance [28].

\section{Type V RPTPs}

PTP $\gamma$. PTP $\gamma$ is expressed widely in the nervous system, both centrally and peripherally [29]. Animals deficient in Ptprg develop with anatomically fairly normal nervous systems, although behavioural changes are observed [30, 31] (see below). In the chick embryo model, this phosphatase is implicated in spinal neurogenesis [32]. More recently PTP $\gamma$ has also be implicated in the neurite outgrowth of rat cortical neurons [33].

The influence of PTP $\gamma$ over neurite outgrowth appears to be founded on its interactions with contactins, a family of GPI-anchored adhesion molecules [34, 35]. PTP $\gamma$ binds to contactins $3,4,5$ and 6 via its carbonic anhydrase-like N-terminal domain, whereas the closely related PTP $\zeta$ binds only contactin1 [34]. For PTP $\gamma$, the role of these contactin interactions has remained uncertain. However, secretion of soluble forms of contactins 4,5 and 6 in co-cultures show that these can increase neurite length, branching and number of neurites per cell in cortical neurons, although these effects were modest and apparently transient [33]. Contactins, as well as PTP $\gamma$, can be cellassociated or shed from cell surfaces [36,37] and the physiological consequences of these potentially complex PTP $\gamma$-contactin interactions remain to be determined in vivo. Contactins may also share PTP $\alpha$ as a binding partner [38]. Thus although mice lacking Ptprg do not show obvious nerve development problems, subtle problems with nerve network formation during development may give rise in part to the behavioural defects observed [30, 31].

PTP $\zeta$. PTP $\zeta$ is related closely to PTP $\gamma$ and its gene encodes several protein isoforms, including a major secreted isoform, phosphacan. Because of this, different isoforms can have cell-autonomous or non-cell-autonomous actions over neurite formation. For example, it can have a cell-autonomous, suppressive effect over NGF-induced neuritogenesis in PC12 cells. This is thought to operate through tyrosine 
dephosphorylation of the neurotrophin receptor TRKA [39]. PTP $\zeta$ is also thought to send signals in trans (non-cell-autonomously) to neurons, through neuronal contactin and NrCAM. This stimulates neurite outgrowth from chick tectal cells [40]. PTP $\zeta$ binds to contactin 1 selectively, distinguishing it from the contactin ligands of PTP $\gamma[34,41$, 42]. РТP $\zeta$ also has pleiotropin as an extracellular ligand and there is a suggestion that this interaction directly influences neuritogenesis. This effect may be somewhat indirect though [43], as may be the proposed ability of PTP $\zeta$ to direct morphogenesis of dendritic spines on Bergmann glia [44]. In Xenopus, cranial nerve elongation and fasciculation are defective after overexpression of various PTP $\zeta$ isoforms [45]. However, again these effects may well be non-cell autonomous, since the secreted form of PTP $\zeta$ was equally effective. The physiological relevance of such overexpression approaches has also to be treated with caution.

Mice deficient for the Ptprz gene develop apparently normally [46]. Nevertheless, it is feasible that effects might by masked by the compensatory actions of other PTPs. In summary, the role of PTP $\zeta$ isoforms in neural development is complex, positioned as it is on both neurons and glia and with major transmembrane and secreted isoforms with distinct roles [47] (see Harroch chapter).

\subsection{RPTPs and Nerve regeneration.}

With their roles in axon growth and guidance, it is unsurprising that RPTPs influence the regeneration of nerves, with PTP $\sigma$ being of particular interest. PTPodeficiency leads to increased sciatic nerve repair in mice (albeit with local guidance errors) [48], better optic nerve regeneration after nerve crush [49], and improved facial nerve regeneration [50]. Corticospinal tract regeneration is also improved in the absence of PTPG, and cultured cerebellar granule neurons show reduced inhibition by CSPGs [51]. In contrast, type IIA LAR-deficiency appears to lead to reduced sciatic regeneration $[52,53]$. Looking at type V RPTPs, remyelination is defective in PTP $\zeta$ deficient mice, although this may be largely an oligodendrocytic role [54].

\subsection{RPTPs in in synaptogenesis}

2.1 Pre-synaptic roles. RPTPs remain strongly expressed in the nervous system after their requirements during axon growth and guidance events have finished. Thereafter, we now know that a major role resides in the synapse. The first clue came in 2006, when Drosophila DLAR was shown to bind the HSPGs Dally-like and Syndecan. These interactions regulated either presynapse formation (Syndecan:Dlar), or remodeling of active synapses (Dally-like:DLAR) [13]. Mammalian LAR was soon implicated in synapse 
formation in hippocampal neurons [55]. More recent research of presynaptic PTPб in zebrafish shows that PTPo prevents excessive numbers of synapses from forming in terminals of olfactory sensory neurons, but it does not actually control normal synapse formation [56]. Given these indications of synaptic roles, it is gratifying to now see a number of key synaptic partners identified for these RPTPs, cementing their importance as synaptic regulators. As this area is fast moving and has been reviewed recently [5759], we will give only an overview.

In 2009, Woo discovered that LAR expressed in Cos7 cells can trigger presynaptic maturation in co-cultured hippocampal neurons. This was through interaction of LAR FNIII domains with netrin-G ligand-3 (NGL-3) [60]. NGL3 is expressed widely in neurons and is a postsynaptic adhesion molecule that complexes with PSD95 [61]. PTP $\sigma$ can also interact with NGL-3 to promote synapse formation bidirectionally, and PTPS-NGL-3 interactions promote pre-synaptic maturation unidirectionally [62]. Furthermore, PTP $\delta$ has recently been shown to bind to ILRap1 $[63,64]$, PTP $\sigma$ binds to synaptic neurotrophin receptor TRKC [65], PTP $\sigma$ and PTP $\delta$ bind to Slitrk synaptic proteins of the leucine rich repeat family [66-68] and all three type IIA RPTPs bind to synaptic IL1RAcP (PTPS the strongest [69]). In Takahashi's comprehensive review, these multiplex interactions are described as synaptic hubs, akin to those found with neurexins and neuroligins [70]. Such hubs may facilitate a range of diverse pre- and post-synaptic responses, in both excitatory and inhibitory synapses. Certainly there is ample opportunity for these RPTPs to interact with individual or multiple trans-synaptic partners, as adhesion molecules, clustering complexes and presynaptic phosphatase signalling centres. The structural basis for the extracellular interactions and their modulation by splicing is discussed further in chapter $\mathrm{N}$ (Coles)

The TRKC interaction with PTP $\sigma$ is interesting given that type IIA RPTPs are also cis interactors of TRKs and regulators of TRK signalling [71, 72]. As NT3 binds to TRKC using different domains than PTPo, it remains to be seen how NT3 may influence, or be influenced by, TrkC-RPTP interactions.

The interactions of RPTPs with a growing number of postsynaptic partners, points to a potential range of diverse, combinatorial and dynamic signaling. This would sit perfectly with the requisite dynamics of synaptic plasticity. Further modulation of trans-synaptic interactions by alternative splice variations of the RPTPs, may provide another level of post-transcriptional control. For example in the ectodomain of type IIA RPTPs, alternate mini-exons named meA and meB in the immunoglobulin domains are 
able to determine the affinity of interactions with TRKC, IL1rAP and Slitrks [57, 64, 69]. RPTP interactions in synapses may also be modulated by local interactions HSPGs and CSPGs $[22,73]$, in a similar vein to that found with Drosophila DLAR [13]. These interactions may be significant given that mammalian dendritic spines and synapses are clearly influenced by proteoglycans $[74,75]$. Since proteoglycans and TRKC have overlapping binding sites on PTP $\sigma$, the proteoglycans could well modify RPTPdependent trans-synaptic signals, by interfering with TRKC binding (see also Coles chapter).

Further signaling complexity may arises from the release of cell surface RPTP ectodomains through gamma secretase action [76, 77] (Figure 1). Gamma secretases are proteases within synapses with relevance to diseases such as Alzheimer's [78]. Indeed they act upon NGL3 to influence LTD in brain slices [79]. If gamma secretase regulation is central to the rapid modulation on intra-synaptic hubs, then the RPTPs are very likely to be targeted as well. RPTP ectodomain shedding could then be part of either a downregulation pathway, or the solubilized ectodomains could themselves act locally to modulate other synaptic interactions.

2.2 Pre-synaptic signaling. In the pre-synaptic active zone, it appears that type IIA RPTP help to promote differentiation and recruitment of pre-synaptic vesicles. How RPTPs do this is largely unclear, but there is definitely one link from RPTPs to vesicular control through the multidomain scaffolding protein Liprin- $\alpha$ [80]. Established largely in Drosophila and C.elegans. model systems, Liprin- $\alpha$ may be the crucial link from type IIA phosphatases to partners such as CASK and RIM, enabling control of active zone dynamics (reviewed in [81]).

2.3 Post-synaptic roles. RPTPs also function in post-synaptic membranes (reviewed in [59]). LAR is implicated in the delivery of cadherins and $\alpha$-amino-3-hydroxy-5-methyl4-isoxazolepropionic acid (AMPA) receptors to nascent excitatory synapses, possibly through a scaffolding role with liprin- $\alpha, \beta$-catenin and GRIP [55]. Once in the synapse, LAR is also believed to control phosphorylation of AMPAR, leading to AMPAR internalization and contributing to LTD. LAR can also associate with PSD95 and may have a broader role in dendritic spine formation. This is supported by the fact that RNAiinduced reduction in LAR, or in fact any of the type IIA RPTPs, leads to reduced dendritic spine numbers and AMPAR GluR2 density in hippocampal neurons [55]. For type IV RPTPs, PTP $\alpha$ is a positive regulator of post-synaptic NMDA receptor subunits NR2A and 
NR2B, wherein the PTP activates SRC family and PYK tyrosine kinases, leading to increased NMDAR phosphorylation and activation [82]. Other RPTPs may potentially modulate other post-synaptic receptors in cis, including TRKC for example, given its interactions with type IIA RPTPs and PTPRO $[71,83]$.

\section{RPTPs in memory, synaptic function and neurological disorders}

In 2006 it was shown that Drosophila rely on PTP10D to control long term memory, specifically within mushroom bodies, and that this ongoing function was required for plasticity during memory formation itself. In other words, it showed that memory deficits were not caused by an earlier, neurodevelopmental defect [84]. Most engineered mouse strains that have germline loss of RPTP genes, although outwardly normal in many cases, later revealed subtle learning and behavioural deficits (Table 1) [57]. In the following examples, it should noted that it remains largely unclear what proportion of each phenotype is caused by on-going, synaptic dysfunction, or an underlying developmental defect of mis-wiring.

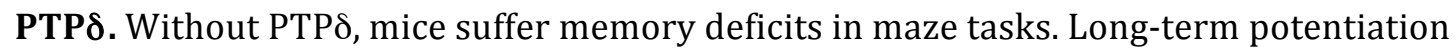
(LTP) induced in hippocampal synapses is also enhanced [85]. Genetic evidence in humans points to PTP $\delta$ being involved in restless legs syndrome and in attention-deficit hyperactivity disorder (ADHD) [57, 86, 87].

LAR. Loss of LAR catalytic domains in the mouse germline leads to mild spatial learning defects and some increase in nocturnal activity [88].

PTPRO. PTPRO-deficient mice have nociceptive deficits. However, these may be caused by developmental loss of sensory neurons and nociceptive circuits, rather than a PTPRO-dependent synaptic dysfunction [28].

PTP $\gamma$. PTP $\gamma$-deficiency causes mild behavioural changes including poor, cued fear conditioning and altered processing of acoustic stimuli [31]. A later study revealed antidepressant-like behaviours [30]. This is of interest since genetic lesions in contactin genes, encoding PTP $\gamma$ ligands, are implicated in autism spectrum disorders [89].

PTP $\zeta$. PTP $\zeta$-deficiency leads to some age-related impairment in motor performance and skills development, and reduced nociceptive responses [90]. There is also enhancement of LTP, potentially functioning through dephosphorylation of RhoGAP by PTP $\zeta$, affecting Rho GTPase action [91].

PTP $\alpha$. Mice lacking PTP $\alpha$ have significant deficiencies in LTP in CA1 pyramidal neurons $[92,93]$. They have learning and neuroplasticity defects, but their behaviour is otherwise largely similar to wild type mice. 
Of great interest for the type IIA enzymes is the fact that ligand genes including SLITRKs, TRKC and IL1RAPL1, have each been genetically implicated in neuropsychiatric disorders in man (reviewed in ref. 58). The extent to which the RPTPs themselves might influence these neuropsychiatric phenotypes in humans remains to be seen, but the possibility that these could be translated into therapeutic strategies is an enticing prospect.

\section{Conclusion}

RPTP enzymes are now functionally recognised in controlling axonogenesis as well as synapse structure and function. The elegant complementarity between their developmental and adult roles, highlights how proteins are re-deployed during ontogeny. How multiple RPTP members co-exist in individual neurons in a balanced regulatory network [94] and how this might influence drug targeting strategies, are key questions. Nevertheless, their influence over nerve regeneration could prove highly relevant to CNS trauma treatment. Moreover, with their potential links to neuropsychiatric disorders, RPTPs could represent an exciting new class of therapeutic targets.

\section{Acknowledgements}

A.W.Stoker is funded by the Neuroblastoma Society UK (11ND22) and Great Ormond Street Children's Charity (2012-NAT-30). Thanks go to Samuel Bouyain for requesting this review. Apologies are made for the omission of many relevant references, due to space limitations. 


\section{Figure Legends}

\section{Figure 1}

Schematic structures of vertebrate RPTPs, with protein sub-domains indicated. Where secreted or cleaved ectodomains are documented, these are shown to the left of the fulllength proteins. The known roles of these RPTPs are indicated for (i) synaptic development or plasticity, (ii) axon guidance, or (iii) axon elongation and regeneration.

\section{Figure 2}

Genetic interaction between pairs of RPTPs in Drosophila, chick and mouse. Gene names, their relationship to vertebrate orthologues and their tissue location are indicated for fly RPTPs (NCO: no clear vertebrate orthologue, see Andersen 2005; A, axons only; A+N, axons plus neuronal cell bodies; broad, broad embryo expression). Panel A, adapted from Jeon et al. [10]. Doubleheaded arrow indicates synthetic genetic relationship; single arrows indicates enhancement of genetic effect, or cooperation; blunt ends indicate genetic suppression. Thicker lines indicate larger effects. Blue dashed lines indicate RPTP interactions in motor axons, black lines indicate longitudinal axon interactions. Panel B, Genetic interactions in spinal motor nerves in the chick (mutual suppression of phenotype [24]), or in phrenic nerves in mice (synthetic interaction [26]). 
Table 1

\begin{tabular}{|c|c|c|c|c|c|c|c|}
\hline RPTP & $\begin{array}{c}\text { neurite } \\
\text { growth \& } \\
\text { regeneration }\end{array}$ & $\begin{array}{c}\text { axon } \\
\text { guidance }\end{array}$ & $\begin{array}{c}\text { synapse } \\
\text { formation } \\
\text { \& plasticity }\end{array}$ & $\begin{array}{l}\text { behavioural } \\
\text { changes in gene- } \\
\text { deficient mice }\end{array}$ & ligand* & $\begin{array}{l}\text { cis partners/ } \\
\text { effectors in } \\
\text { neural cells }\end{array}$ & refs \\
\hline PTP $\alpha$ & rodent & & rodent & $\begin{array}{l}\text { Modest learning and } \\
\text { neuroplasticity } \\
\text { deficits; LTP deficit }\end{array}$ & & $\begin{array}{c}\text { NCAM, FGFR, FYN, } \\
\text { SRC, PYK, } \\
\text { CaMKIIalpha, GRB2, } \\
\text { PSD95 }\end{array}$ & $\begin{array}{l}{[92,93,} \\
95-97]\end{array}$ \\
\hline РТР५ & $\begin{array}{l}\text { Xenopus, } \\
\text { rodent }\end{array}$ & & & $\begin{array}{l}\text { Enhanced LTP; } \\
\text { memory deficits }\end{array}$ & $\begin{array}{c}\text { Contactin, } \\
\text { Pleiotrophin }\end{array}$ & TRKA & $\begin{array}{c}33,34 \\
39-43 \\
45,90] \\
\end{array}$ \\
\hline PTPy & rodent & & & $\begin{array}{c}\text { Anti-depressive } \\
\text { behaviour; reduced } \\
\text { fear conditioning } \\
\text { responses }\end{array}$ & Contactins 3-6 & $\begin{array}{c}\beta \text {-catenin } \\
\text { p13(suc1) }\end{array}$ & $\begin{array}{c}{[30,31,} \\
34,98]\end{array}$ \\
\hline PTPס & $\begin{array}{c}\text { Хenopus, } \\
\text { rodent, man }\end{array}$ & rodent & rodent & $\begin{array}{l}\text { Memory deficits in } \\
\text { maze tasks; } \\
\text { enhanced LTP; } \\
\text { genetic linkage in } \\
\text { man to restless legs } \\
\text { syndrome and } \\
\text { ADHD. }\end{array}$ & $\begin{array}{l}\text { Self, NGL-3, } \\
\text { IL1RAcP\#, } \\
\text { IL1RAPL1, } \\
\text { SLTRK3 }^{+}\end{array}$ & Liprin- $\alpha$ & $\begin{array}{c}{[24,26,} \\
60,63, \\
64,67-69, \\
86,87, \\
99,100]\end{array}$ \\
\hline PTPo & $\begin{array}{l}\text { Chick, rodent, } \\
\text { Xenopus }\end{array}$ & chick & rodent & & $\begin{array}{l}\text { HSPG, CSPG, } \\
\text { NGL-3, } \\
\text { SLTRK1,2,4-6 }{ }^{\dagger}, \\
\text { IL1RAcP, } \\
\text { NUCLEOLIN, } \\
\text { TRKC }\end{array}$ & $\begin{array}{l}\text { TRKs, RAC GTPase } \\
\text { activity through } \\
\text { p250GAP, } \\
\text { Liprin- } \alpha\end{array}$ & $\begin{array}{c}24,25, \\
48-51,60, \\
67,69 \\
71,100- \\
102]\end{array}$ \\
\hline LAR & $\begin{array}{l}\text { rodent, } \\
\text { Xenopus }\end{array}$ & & rodent & $\begin{array}{c}\text { Spatial learning } \\
\text { deficits and } \\
\text { increased nocturnal } \\
\text { activity } \\
\end{array}$ & $\begin{array}{l}\text { Self, NGL-3, } \\
\text { IL1RAcP }\end{array}$ & $\begin{array}{l}\text { Liprin- } \alpha \\
\text { TRKB }\end{array}$ & $\begin{array}{c}{[52,53,55,60,} \\
62,69,72,88, \\
100]\end{array}$ \\
\hline PTPRO & $\begin{array}{l}\text { Chick, } \\
\text { rodent }\end{array}$ & chick & & Nociceptive deficits & & & {$[24,28,83]$} \\
\hline
\end{tabular}

Text in italics indicates where in vivo evidence is documented

* Ligands with likely physiological relevance; other in vitro interactions are seen [57]

$+\quad$ inhibitory synapse for PTPS ; excitatory synapse for PTPo

『 non-cell autonomous action on neurons, through either PTP $\zeta$ expression on glia, or phosphacan

\# PTPS binds more strongly to IL1RacP than PTPo or LAR (ref [69]) 


\section{References}

[1] Andersen JN, Del Vecchio RL, Kannan N, Gergel J, Neuwald AF, Tonks NK. Computational analysis of protein tyrosine phosphatases: practical guide to bioinformatics and data resources. Methods 2005;35:90-114.

[2] Ensslen-Craig SE, Brady-Kalnay SM. Receptor protein tyrosine phosphatases regulate neural development and axon guidance. Dev Biol 2004;275:12-22.

[3] Johnson K, Van Vactor D. Receptor Protein Tyrosine Phosphatases in Nervous System Development. Physiological Reviews 2003;83:1-24.

[4] Tayler TD, Garrity PA. Axon targeting in the Drosophila visual system. Curr Opin Neurobiol 2003;13:90-5.

[5] Mast JD, Prakash S, Chen P-L, Clandinin TR. The mechanisms and molecules that connect photoreceptor axons to their targets in Drosophila. Semin Cell Dev Biol 2006;17:42-9.

[6] Garrity P, Lee C, Salecker I, Robertson H. Retinal Axon Target Selection in Drosophila Is Regulated by a Receptor Protein Tyrosine Phosphatase. Cell 2000.

[7] Hofmeyer K, Treisman JE. The receptor protein tyrosine phosphatase LAR promotes R7 photoreceptor axon targeting by a phosphatase-independent signaling mechanism. Proc Natl Acad Sci U S A 2009.

[8] Kurusu M, Zinn K. Receptor tyrosine phosphatases regulate birth order-dependent axonal fasciculation and midline repulsion during development of the Drosophila mushroom body. Mol Cell Neurosci 2008;38:53-65.

[9] Schindelholz B, Knirr M, Warrior R, Zinn K. Regulation of CNS and motor axon guidance in Drosophila by the receptor tyrosine phosphatase DPTP52F. Development 2001;128:4371-82.

[10] Jeon M, Nguyen H, Bahri S, Zinn K. Redundancy and compensation in axon guidance: genetic analysis of the Drosophila Ptp10D/Ptp4E receptor tyrosine phosphatase subfamily. Neural development 2008;3:3.

[11] Sun Q, Schindelholz B, Knirr M, Schmid A, Zinn K. Complex genetic interactions among four receptor tyrosine phosphatases regulate axon guidance in Drosophila. Mol Cell Neurosci 2001;17:274-91.

[12] Desai CJ, Gindhart JG, Jr., Goldstein LS, Zinn K. Receptor tyrosine phosphatases are required for motor axon guidance in the Drosophila embryo. Cell 1996;84:599-609. [13] Johnson KG, Tenney AP, Ghose A, Duckworth AM, Higashi ME, Parfitt K, et al. The HSPGs Syndecan and Dallylike Bind the Receptor Phosphatase LAR and Exert Distinct Effects on Synaptic Development. Neuron 2006;49:517-31.

[14] Fox AN, Zinn K. The Heparan Sulfate Proteoglycan Syndecan Is an In Vivo Ligand for the Drosophila LAR Receptor Tyrosine Phosphatase. Curr Biol 2005;15:1701-11.

[15] Prakash S, McLendon HM, Dubreuil CI, Ghose A, Hwa J, Dennehy KA, et al. Complex interactions amongst N-cadherin, DLAR, and Liprin-alpha regulate Drosophila photoreceptor axon targeting. Dev Biol 2009;336:10-9.

[16] Lee HK, Cording A, Vielmetter J, Zinn K. Interactions between a receptor tyrosine phosphatase and a cell surface ligand regulate axon guidance and glial-neuronal communication. Neuron 2013;78:813-26.

[17] Schonbaum CP, Organ EL, Qu S, Cavener DR. The Drosophila melanogaster stranded at second (sas) gene encodes a putative epidermal cell surface receptor required for larval development. Dev Biol 1992;151:431-45.

[18] Sajnani G, Aricescu AR, Jones EY, Gallagher J, Alete D, Stoker A. PTPsigma promotes retinal neurite outgrowth non-cell-autonomously. J Neurobiol 2005;65:59-71.

[19] Yang T, Bernabeu R, Xie Y, Zhang JS, Massa SM, Rempel HC, et al. Leukocyte antigenrelated protein tyrosine phosphatase receptor: a small ectodomain isoform functions as a homophilic ligand and promotes neurite outgrowth. J Neurosci 2003;23:3353-63.

[20] Yang T, Yin W, Derevyanny VD, Moore LA, Longo FM. Identification of an ectodomain within the LAR protein tyrosine phosphatase receptor that binds 
homophilically and activates signalling pathways promoting neurite outgrowth. Eur J Neurosci 2005;22:2159-70.

[21] Tisi MA, Xie Y, Yeo TT, Longo FM. Downregulation of LAR tyrosine phosphatase prevents apoptosis and augments NGF-induced neurite outgrowth. J Neurobiol 2000;42:477-86.

[22] Coles CH, Shen Y, Tenney AP, Siebold C, Sutton GC, Lu W, et al. Proteoglycan-specific molecular switch for RPTPsigma clustering and neuronal extension. Science 2011;332:484-8.

[23] Johnson KG, McKinnell IW, Stoker AW, Holt CE. Receptor protein tyrosine phosphatases regulate retinal ganglion cell axon outgrowth in the developing Xenopus visual system. J Neurobiol 2001;49:99-117.

[24] Stepanek L, Stoker AW, Stoeckli E, Bixby JL. Receptor tyrosine phosphatases guide vertebrate motor axons during development. J Neurosci 2005;25:3813-23.

[25] Rashid-Doubell F, McKinnell I, Aricescu AR, Sajnani G, Stoker A. Chick PTPsigma regulates the targeting of retinal axons within the optic tectum. J Neurosci 2002;22:5024-33.

[26] Uetani N, Chagnon MJ, Kennedy TE, Iwakura Y, Tremblay ML. Mammalian motoneuron axon targeting requires receptor protein tyrosine phosphatases sigma and delta. J Neurosci 2006;26:5872-80.

[27] Shintani T, Ihara M, Sakuta H, Takahashi H, Watakabe I, Noda M. Eph receptors are negatively controlled by protein tyrosine phosphatase receptor type 0 . Nat Neurosci 2006;9:761-9.

[28] Gonzalez-Brito MR, Bixby JL. Protein tyrosine phosphatase receptor type 0 regulates development and function of the sensory nervous system. Mol Cell Neurosci 2009;42:458-65.

[29] Lamprianou S, Harroch S. Receptor protein tyrosine phosphatase from stem cells to mature glial cells of the central nervous system. Journal of molecular neuroscience : MN 2006;29:241-55.

[30] Zhang W, Savelieva KV, Tran DT, Pogorelov VM, Cullinan EB, Baker KB, et al. Characterization of PTPRG in Knockdown and Phosphatase-Inactive Mutant Mice and Substrate Trapping Analysis of PTPRG in Mammalian Cells. PLoS One 2012;7:e45500. [31] Lamprianou S, Vacaresse N, Suzuki Y, Meziane H, Buxbaum JD, Schlessinger J, et al. Receptor protein tyrosine phosphatase gamma is a marker for pyramidal cells and sensory neurons in the nervous system and is not necessary for normal development. Mol Cell Biol 2006;26:5106-19.

[32] Hashemi H, Hurley M, Gibson A, Panova V, Tchetchelnitski V, Barr A, et al. Receptor tyrosine phosphatase PTPgamma is a regulator of spinal cord neurogenesis. Molecular and cellular neurosciences 2011;46:469-82.

[33] Mercati O, Danckaert A, Andre-Leroux G, Bellinzoni M, Gouder L, Watanabe K, et al. Contactin $4,-5$ and -6 differentially regulate neuritogenesis while they display identical PTPRG binding sites. Biology open 2013;2:324-34.

[34] Bouyain S, Watkins DJ. The protein tyrosine phosphatases PTPRZ and PTPRG bind to distinct members of the contactin family of neural recognition molecules. Proc Natl Acad Sci U S A 2010;107:2443-8.

[35] Bouyain S, Watkins DJ. Identification of tyrosine phosphatase ligands for contactin cell adhesion molecules. Commun Integr Biol 2010;3:284-6.

[36] Sharom FJ, Lehto MT. Glycosylphosphatidylinositol-anchored proteins: structure, function, and cleavage by phosphatidylinositol-specific phospholipase C. Biochem Cell Biol 2002;80:535-49.

[37] Shintani T, Maeda N, Nishiwaki T, Noda M. Characterization of rat receptor-like protein tyrosine phosphatase gamma isoforms. Biochem Biophys Res Commun 1997;230:419-25. 
[38] Zeng L, D'Alessandri L, Kalousek MB, Vaughan L, Pallen CJ. Protein Tyrosine Phosphatase alpha (PTPalpha) and Contactin Form a Novel Neuronal Receptor Complex Linked to the Intracellular Tyrosine Kinase fyn. J Cell Biol 1999;147:707-14.

[39] Shintani T, Noda M. Protein tyrosine phosphatase receptor type Z dephosphorylates TrkA receptors and attenuates NGF-dependent neurite outgrowth of PC12 cells. Journal of Biochemistry 2008;144:259-66.

[40] Milev P, Chiba A, Haring M, Rauvala H, Schachner M, Ranscht B, et al. High affinity binding and overlapping localization of neurocan and phosphacan/protein-tyrosine phosphatase-zeta/beta with tenascin-R, amphoterin, and the heparin-binding growthassociated molecule. J Biol Chem 1998;273:6998-7005.

[41] Sakurai T, Lustig M, Nativ M, Hemperly JJ, Schlessinger J, Peles E, et al. Induction of neurite outgrowth through contactin and $\mathrm{Nr}-\mathrm{CAM}$ by extracellular regions of glial receptor tyrosine phosphatase beta. J Cell Biol 1997;136:907-18.

[42] Peles E, Nativ M, Campbell PL, Sakurai T, Martinez R, Lev S, et al. The carbonic anhydrase domain of receptor tyrosine phosphatase beta is a functional ligand for the axonal cell recognition molecule contactin. Cell 1995;82:251-60.

[43] Fukazawa N, Yokoyama S, Eiraku M, Kengaku M, Maeda N. Receptor-Type Protein Tyrosine Phosphatase \{zeta\} -Pleiotrophin Signaling Controls Endocytic Trafficking of DNER that Regulates Neuritogenesis. Mol Cell Biol 2008.

[44] Tanaka M, Maeda N, Noda M, Marunouchi T. A chondroitin sulfate proteoglycan PTPzeta /RPTPbeta regulates the morphogenesis of Purkinje cell dendrites in the developing cerebellum. J Neurosci 2003;23:2804-14.

[45] Nagata S, Yamada Y, Saito R, Fujita N. Overexpression of receptor-type protein tyrosine phosphatase beta causes abnormal development of the cranial nerve in Xenopus embryos. Neurosci Lett 2003;349:175-8.

[46] Harroch S, Palmeri M, Rosenbluth J, Custer A, Okigaki M, Shrager P, et al. No obvious abnormality in mice deficient in receptor protein tyrosine phosphatase beta [In Process Citation]. Mol Cell Biol 2000;20:7706-15.

[47] Faissner A, Heck N, Dobbertin A, Garwood J. DSD-1-Proteoglycan/Phosphacan and receptor protein tyrosine phosphatase-beta isoforms during development and regeneration of neural tissues. Adv Exp Med Biol 2006;557:25-53.

[48] McLean J, Batt J, Doering LC, Rotin D, Bain JR. Enhanced rate of nerve regeneration and directional errors after sciatic nerve injury in receptor protein tyrosine phosphatase sigma knock-out mice. J Neurosci 2002;22:5481-91.

[49] Sapieha PS, Duplan L, Uetani N, Joly S, Tremblay ML, Kennedy TE, et al. Receptor protein tyrosine phosphatase sigma inhibits axon regrowth in the adult injured CNS. Mol Cell Neurosci 2005;28:625-35.

[50] Thompson KM, Uetani N, Manitt C, Elchebly M, Tremblay ML, Kennedy TE. Receptor protein tyrosine phosphatase sigma inhibits axonal regeneration and the rate of axon extension. Mol Cell Neurosci 2003;23:681-92.

[51] Fry EJ, Chagnon MJ, Lopez-Vales R, Tremblay ML, David S. Corticospinal tract regeneration after spinal cord injury in receptor protein tyrosine phosphatase sigma deficient mice. Glia 2010;58:423-33.

[52] Xie Y, Yeo TT, Zhang C, Yang T, Tisi MA, Massa SM, et al. The leukocyte common antigen-related protein tyrosine phosphatase receptor regulates regenerative neurite outgrowth in vivo. J Neurosci 2001;21:5130-8.

[53] Van Der Zee CE, Man TY, Van Lieshout EM, Van Der Heijden I, Van Bree M, Hendriks WJ. Delayed peripheral nerve regeneration and central nervous system collateral sprouting in leucocyte common antigen-related protein tyrosine phosphatase-deficient mice. Eur J Neurosci 2003;17:991-1005.

[54] Harroch S, Furtado GC, Brueck W, Rosenbluth J, Lafaille J, Chao M, et al. A critical role for the protein tyrosine phosphatase receptor type $\mathrm{Z}$ in functional recovery from demyelinating lesions. Nat Genet 2002;32:411-4. 
[55] Dunah AW, Hueske E, Wyszynski M, Hoogenraad CC, Jaworski J, Pak DT, et al. LAR receptor protein tyrosine phosphatases in the development and maintenance of excitatory synapses. Nat Neurosci 2005;8:458-67.

[56] Chen X, Yoshida T, Sagara H, Mikami Y, Mishina M. Protein tyrosine phosphatase sigma regulates the synapse number of zebrafish olfactory sensory neurons. Journal of Neurochemistry 2011.

[57] Takahashi H, Craig AM. Protein tyrosine phosphatases PTPdelta, PTPsigma, and LAR: presynaptic hubs for synapse organization. Trends Neurosci 2013;36:522-34.

[58] Um JW, Ko J. LAR-RPTPs: synaptic adhesion molecules that shape synapse development. Trends Cell Biol 2013;23:465-75.

[59] Hendriks WJ, Elson A, Harroch S, Pulido R, Stoker A, den Hertog J. Protein tyrosine phosphatases in health and disease. FEBS J 2013;280:708-30.

[60] Woo J, Kwon S-K, Choi S, Kim S, Lee J-R, Dunah AW, et al. Trans-synaptic adhesion between NGL-3 and LAR regulates the formation of excitatory synapses. Nat Neurosci 2009;12:428-37.

[61] Woo J, Kwon SK, Kim E. The NGL family of leucine-rich repeat-containing synaptic adhesion molecules. Mol Cell Neurosci 2009;42:1-10.

[62] Kwon SK, Woo J, Kim SY, Kim H, Kim E. Trans-synaptic adhesions between netrin-G ligand-3 (NGL-3) and receptor tyrosine phosphatases LAR, protein-tyrosine phosphatase delta (PTPdelta), and PTPsigma via specific domains regulate excitatory synapse formation. The Journal of biological chemistry 2010;285:13966-78.

[63] Valnegri P, Montrasio C, Brambilla D, Ko J, Passafaro M, Sala C. The X-linked intellectual disability protein IL1RAPL1 regulates excitatory synapse formation by binding PTP\{delta\} and RhoGAP2. Hum Mol Genet 2011.

[64] Yoshida T, Yasumura M, Uemura T, Lee SJ, Ra M, Taguchi R, et al. IL-1 Receptor Accessory Protein-Like 1 Associated with Mental Retardation and Autism Mediates Synapse Formation by Trans-Synaptic Interaction with Protein Tyrosine Phosphatase \{delta\}. The Journal of neuroscience : the official journal of the Society for Neuroscience 2011;31:13485-99.

[65] Takahashi H, Arstikaitis P, Prasad T, Bartlett TE, Wang YT, Murphy TH, et al. Postsynaptic TrkC and Presynaptic PTP $\sigma$ Function as a Bidirectional Excitatory Synaptic Organizing Complex. Neuron 2011;69:287-303.

[66] Ko J. The leucine-rich repeat superfamily of synaptic adhesion molecules: LRRTMs and Slitrks. Molecules and cells 2012;34:335-40.

[67] Yim YS, Kwon Y, Nam J, Yoon HI, Lee K, Kim DG, et al. Slitrks control excitatory and inhibitory synapse formation with LAR receptor protein tyrosine phosphatases. Proc Natl Acad Sci U S A 2013;110:4057-62.

[68] Takahashi H, Katayama K, Sohya K, Miyamoto H, Prasad T, Matsumoto Y, et al. Selective control of inhibitory synapse development by Slitrk3-PTPdelta trans-synaptic interaction. Nat Neurosci 2012;15:389-98, S1-2.

[69] Yoshida T, Shiroshima T, Lee SJ, Yasumura M, Uemura T, Chen X, et al. Interleukin-1 receptor accessory protein organizes neuronal synaptogenesis as a cell adhesion molecule. J Neurosci 2012;32:2588-600.

[70] Graf ER, Zhang X, Jin S-X, Linhoff MW, Craig AM. Neurexins induce differentiation of GABA and glutamate postsynaptic specializations via neuroligins. Cell 2004;119:101326.

[71] Faux C, Hawadle M, Nixon J, Wallace A, Lee S, Murray S, et al. PTPsigma binds and dephosphorylates neurotrophin receptors and can suppress NGF-dependent neurite outgrowth from sensory neurons. Biochim Biophys Acta 2007;1773:1689-700.

[72] Yang T, Massa SM, Longo FM. LAR protein tyrosine phosphatase receptor associates with TrkB and modulates neurotrophic signaling pathways. J Neurobiol 2006;66:142036. 
[73] Aricescu AR, McKinnell IW, Halfter W, Stoker AW. Heparan sulfate proteoglycans are ligands for receptor protein tyrosine phosphatase sigma. Mol Cell Biol 2002;22:1881-92.

[74] Irie F, Yamaguchi Y. EPHB receptor signaling in dendritic spine development. Front Biosci 2004;9:1365-73.

[75] Yamaguchi Y. Glycobiology of the synapse: the role of glycans in the formation, maturation, and modulation of synapses. Biochimica et biophysica acta 2002;1573:36976.

[76] Streuli M, Krueger NX, Ariniello PD, Tang M, Munro JM, Blattler WA, et al. Expression of the receptor-linked protein tyrosine phosphatase LAR: proteolytic cleavage and shedding of the CAM-like extracellular region. Embo J 1992;11:897-907. [77] Haapasalo A, Kim DY, Carey BW, Turunen MK, Pettingell WH, Kovacs DM. Presenilin/gamma -secretase-mediated cleavage regulates association of lar receptor tyrosine phosphatase with beta -catenin. J Biol Chem 2007.

[78] Chen Y, Behnisch T. The role of gamma-secretase in hippocampal synaptic transmission and activity-dependent synaptic plasticity. Neurosci Lett 2013;554:16-21. [79] Lee H, Lee EJ, Song YS, Kim E. Long-term depression-inducing stimuli promote cleavage of the synaptic adhesion molecule NGL-3 through NMDA receptors, matrix metalloproteinases and presenilin/gamma-secretase. Philosophical transactions of the Royal Society of London Series B, Biological sciences 2014;369:20130158.

[80] Serra-Pages C, Medley QG, Tang M, Hart A, Streuli M. Liprins, a family of LAR transmembrane protein-tyrosine phosphatase- interacting proteins. J Biol Chem 1998;273:15611-20.

[81] Sudhof TC. The presynaptic active zone. Neuron 2012;75:11-25.

[82] Le HT, Maksumova L, Wang J, Pallen CJ. Reduced NMDA receptor tyrosine phosphorylation in PTPalpha-deficient mouse synaptosomes is accompanied by inhibition of four src family kinases and Pyk2: an upstream role for PTPalpha in NMDA receptor regulation. J Neurochem 2006.

[83] Hower AE, Beltran PJ, Bixby JL. Dimerization of tyrosine phosphatase PTPRO decreases its activity and ability to inactivate TrkC. J Neurochem 2009;110:1635-47. [84] Qian M, Pan G, Sun L, Feng C, Xie Z, Tully T, et al. Receptor-like tyrosine phosphatase PTP10D is required for long-term memory in Drosophila. J Neurosci 2007;27:4396-402. [85] Uetani N, Kato K, Ogura H, Mizuno K, Kawano K, Mikoshiba K, et al. Impaired learning with enhanced hippocampal long-term potentiation in PTPdelta-deficient mice. Embo J 2000;19:2775-85.

[86] Elia J, Gai X, Xie HM, Perin JC, Geiger E, Glessner JT, et al. Rare structural variants found in attention-deficit hyperactivity disorder are preferentially associated with neurodevelopmental genes. Molecular psychiatry 2010;15:637-46.

[87] Schormair B, Kemlink D, Roeske D, Eckstein G, Xiong L, Lichtner P, et al. PTPRD (protein tyrosine phosphatase receptor type delta) is associated with restless legs syndrome. Nat Genet 2008;40:946-8.

[88] Kolkman MJ, Streijger F, Linkels M, Bloemen M, Heeren DJ, Hendriks WJ, et al. Mice lacking leukocyte common antigen-related (LAR) protein tyrosine phosphatase domains demonstrate spatial learning impairment in the two-trial water maze and hyperactivity in multiple behavioural tests. Behav Brain Res 2004;154:171-82.

[89] Zuko A, Bouyain S, van der Zwaag B, Burbach JP. Contactins: structural aspects in relation to developmental functions in brain disease. Advances in protein chemistry and structural biology 2011;84:143-80.

[90] Lafont D, Adage T, Greco B, Zaratin P. A novel role for receptor like protein tyrosine phosphatase zeta in modulation of sensorimotor responses to noxious stimuli: evidences from knockout mice studies. Behav Brain Res 2009;201:29-40.

[91] Tamura H, Fukada M, Fujikawa A, Noda M. Protein tyrosine phosphatase receptor type $\mathrm{Z}$ is involved in hippocampus-dependent memory formation through dephosphorylation at Y1105 on p190 RhoGAP. Neurosci Lett 2006;399:33-8. 
[92] Petrone A, Battaglia F, Wang C, Dusa A, Su J, Zagzag D, et al. Receptor protein tyrosine phosphatase alpha is essential for hippocampal neuronal migration and longterm potentiation. Embo J 2003;22:4121-31.

[93] Skelton MR, Ponniah S, Wang DZ, Doetschman T, Vorhees CV, Pallen CJ. Protein tyrosine phosphatase alpha (PTP alpha) knockout mice show deficits in Morris water maze learning, decreased locomotor activity, and decreases in anxiety. Brain Res 2003;984:1-10.

[94] Tchetchelnitski V, van den Eijnden M, Schmidt F, Stoker AW. Developmental coexpression and functional redundancy of tyrosine phosphatases with neurotrophin receptors in developing sensory neurons. Int J Dev Neurosci 2014;34:48-59.

[95] Bodrikov V, Sytnyk V, Leshchyns'ka I, den Hertog J, Schachner M. NCAM induces CaMKIIalpha-mediated RPTPalpha phosphorylation to enhance its catalytic activity and neurite outgrowth. J Cell Biol 2008;182:1185-200.

[96] Bodrikov V, Leshchyns'ka I, Sytnyk V, Overvoorde J, den Hertog J, Schachner M. RPTPalpha is essential for NCAM-mediated p59fyn activation and neurite elongation. J Cell Biol 2005;168:127-39.

[97] Su J, Yang LT, Sap J. Association between receptor protein-tyrosine phosphatase RPTPalpha and the Grb2 adaptor. Dual Src homology (SH) 2/SH3 domain requirement and functional consequences. J Biol Chem 1996;271:28086-96.

[98] Shintani T, Maeda N, Noda M. Receptor-Like Protein Tyrosine Phosphatase gamma (RPTPgamma), But Not PTPzeta/RPTPbeta, Inhibits Nerve-Growth-Factor-Induced Neurite Outgrowth in PC12D Cells. Dev Neurosci 2001;23:55-69.

[99] Wang J, Bixby JL. Receptor tyrosine phosphatase-delta is a homophilic, neuritepromoting cell adhesion molecular for CNS neurons. Mol Cell Neurosci 1999;14:370-84. [100] Pulido R, Serra Pages C, Tang M, Streuli M. The LAR/PTP delta/PTP sigma subfamily of transmembrane protein-tyrosine-phosphatases: multiple human LAR, PTP delta, and PTP sigma isoforms are expressed in a tissue-specific manner and associate with the LAR-interacting protein LIP.1. Proc Natl Acad Sci U S A 1995;92:11686-90. [101] Chagnon MJ, Wu CL, Nakazawa T, Yamamoto T, Noda M, Blanchetot C, et al. Receptor tyrosine phosphatase sigma (RPTPsigma) regulates, p250GAP, a novel substrate that attenuates Rac signaling. Cell Signal 2010;22:1626-33.

[102] Alete DE, Weeks ME, Hovanession AG, Hawadle M, Stoker AW. Cell surface nucleolin on developing muscle is a potential ligand for the axonal receptor protein tyrosine phosphatase-sigma. Febs J 2006;273:4668-81. 


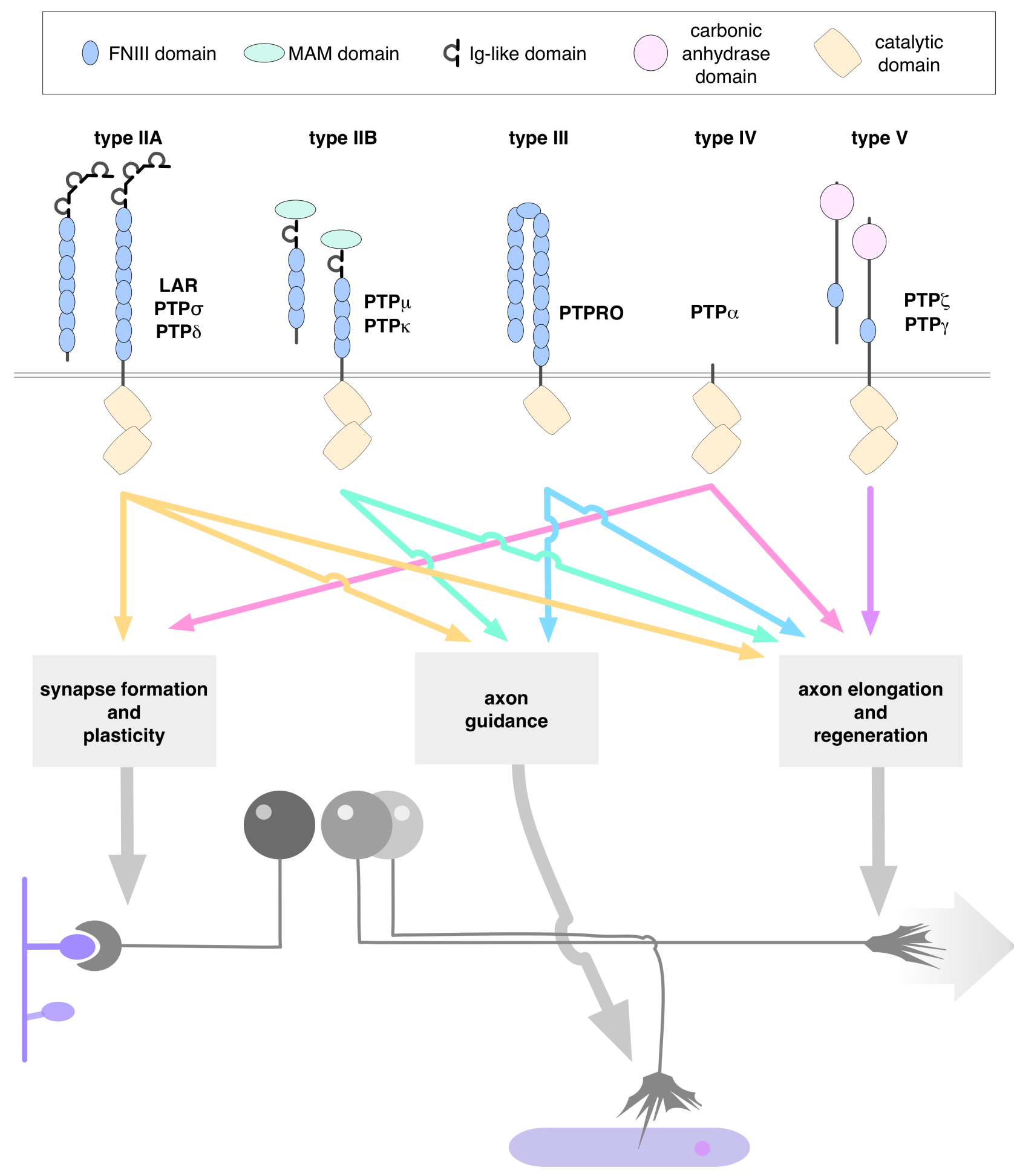

Figure 1

Stoker 
Drosophila

RPTPs

motor axon guidance

CNS longitudinal axon guidance

\section{LAR}

type IIA

CNS (A)

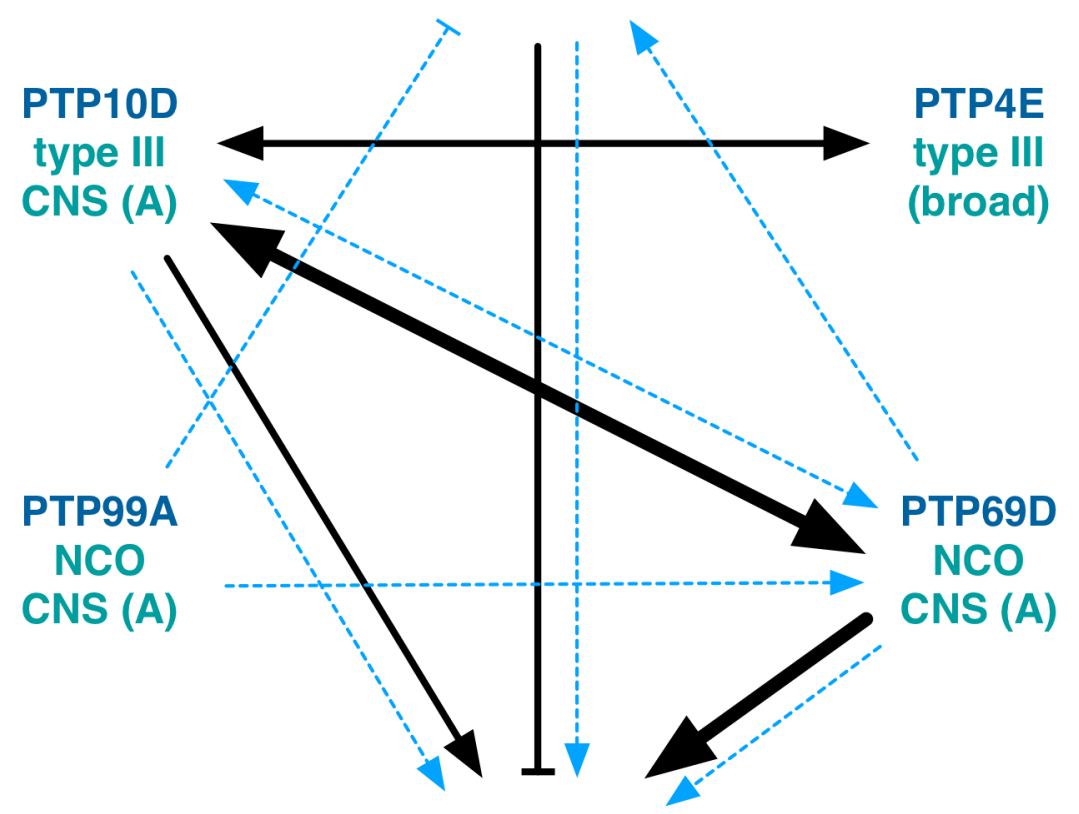

PTP52F

$\mathrm{NCO}$

CNS $(\mathrm{A}+\mathrm{N})$

\section{Vertebrate}

RPTPs

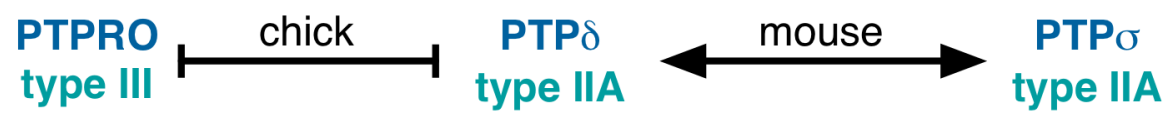

Figure 2

Stoker 